\title{
Crystal structure and chemistry of conichalcite, $\mathrm{CaCu}\left(\mathrm{AsO}_{4}\right)(\mathrm{OH})$
}

\author{
Shunsuke SAKaI ${ }^{*}$, Akira Yoshiasa ${ }^{* *}$, Kazumasa SugIYAMA $^{*}$ and Ritsuro MiYAWAKI ${ }^{* * *}$ \\ *Institute for Materials Research, Tohoku University, Sendai 980-8577, Japan \\ ${ }^{* *}$ Graduate School of Science and Technology, Kumamoto University, \\ Kumamoto 860-8555, Japan \\ ${ }^{* * *}$ Department of Geology, National Science Museum, Tokyo 169-0073, Japan
}

\begin{abstract}
The crystal structures of conichalcite $\left[\mathrm{Ca}(\mathrm{Cu}, \mathrm{Mg})\left(\mathrm{AsO}_{4}\right)(\mathrm{OH})\right]$ samples obtained from Gozaisho mine, Fukushima, Japan, and Higgins mine, Arizona, USA, were refined by single-crystal X-ray diffraction (XRD) using an imaging plate detector. The results revealed that conichalcite is orthorhombic and belongs to the $P 2_{1} 2_{1} 2_{1}$ space group. The positions of the hydrogen atom and the donor and accepter atoms in the structure were determined by difference Fourier and bond-valence sum methods. The crystal comprised three highly distorted coordination polyhedra: an $\mathrm{AsO}_{4}$ tetrahedron, a $\mathrm{CuO}_{4}(\mathrm{OH})_{2}$ octahedron, and a $\mathrm{CaO}_{7}(\mathrm{OH})$ square antiprism. The $\mathrm{CuO}_{4}(\mathrm{OH})_{2}$ octahedron was distorted by the Jahn-Teller effect. The observed As-O distances were shorter than those predicted by ionic bonding. The electronic structure of the atoms affected the distortion of the polyhedra that did not have a symmetry center. The $\mathrm{CuO}_{4}(\mathrm{OH})_{2}$ octahedron shared its edges to form linear chains, which were further linked by the vertices of the $\mathrm{AsO}_{4}$ tetrahedron and the $\mathrm{CaO}_{7}(\mathrm{OH})$ square antiprism to form a threedimensional network. The arrangement of these linear $\mathrm{CuO}_{4}(\mathrm{OH})_{2}$ chains was very similar to that of $\mathrm{CuO}_{6}$ chains in $\mathrm{CuGeO}_{3}$, a spin-Peierls material. Comparisons with several isomorphous minerals revealed that the Jahn-Teller distortion effect caused by $\mathrm{Cu}$ atoms differed significantly between the minerals in the $\mathrm{Ca}$ series and those in the $\mathrm{Pb}$ series. Because of hydrogen bonding, the $\mathrm{Cu}-\mathrm{O}(5)$ and $\mathrm{Cu}-\mathrm{O}(5)^{*}$ distances tended to become shorter than the other $\mathrm{Cu}-\mathrm{O}$ distances in all isomorphous minerals.
\end{abstract}

Keywords: Conichalcite, Crystal structure, Spin structure, Refinement

\section{INTRODUCTION}

Arsenic (As) is abundant in the earth's crust and is an environmental contaminant; one of the major sources of As is the semiconductor industry (mainly in the form of GaAs and InAs). As occurs naturally in sedimentary rocks and is also formed by soil weathering. In particular, $\mathrm{As}^{5+}$ is highly soluble and mobile. Therefore, knowledge of the crystal chemistry of the compounds or minerals of As is important for waste management.

Conichalcite $\left[\mathrm{CaCu}\left(\mathrm{AsO}_{4}\right)(\mathrm{OH})\right]$, also known as calcium cupric hydroxyl arsenate, occurs as a secondary mineral in the oxide zone of base metal ore bodies. Berry (1951) found that conichalcite belongs to the Pnam space group. Then, Qurashi and Barnes (1963) performed more detailed studies and confirmed the determined space

doi: $10.2465 /$ jmps. 080430

A. Yoshiasa, yoshiasa@sci.kumamoto-u.ac.jp Corresponding author group to be $P 2_{1} 2_{1} 2_{1}$. Later, Radcliff and Simmons (1971) carried out an accurate determination of the lattice parameters of conichalcite; according to them, $a=7.393 \AA$, $b=5.830 \AA$, and $c=9.920 \AA$. According to these studies, the crystal structure of conichalcite is a three-dimensional assemblage of an $\mathrm{AsO}_{4}$ tetrahedron, a distorted $\mathrm{CuO}_{4}(\mathrm{OH})$ octahedron, and a $\mathrm{CaO}_{7}(\mathrm{OH})$ square antiprism; these polyhedra share their corners and edges. Conichalcite is a member of the adelite group, which includes adelite $\left[\mathrm{CaMg}\left(\mathrm{AsO}_{4}\right)(\mathrm{OH})\right]$, austinite $\left[\mathrm{CaZn}\left(\mathrm{AsO}_{4}\right)(\mathrm{OH})\right]$, nickel austinite $\left.\left[\mathrm{CaNi}\left(\mathrm{AsO}_{4}\right) \mathrm{OH}\right)\right]$, cobalt austinite $\left[\mathrm{CaCo}\left(\mathrm{AsO}_{4}\right)\right.$ $(\mathrm{OH})]$, duftite $\left[\mathrm{PbCu}\left(\mathrm{AsO}_{4}(\mathrm{OH})\right]\right.$, and gabrielsonite $[\mathrm{PbFe}$ $\left.\left(\mathrm{AsO}_{4}\right)(\mathrm{OH})\right]$. Cation substitutions and the presence of extensive solid solution regions in these minerals have been reported (Taggart and Foord, 1980; Jambor et al., 1980).

The position of the hydrogen atom and anisotropic thermal displacements in the conichalcite structure were not determined precisely in earlier studies. In this study, however, these are determined by structure refinements, 
Table 1. Experimental details and crystallographic data for conichalcite

\begin{tabular}{|c|c|c|}
\hline \multicolumn{3}{|l|}{ Crystal Data: } \\
\hline Locality & Arizona & Fukushima \\
\hline Space group & $P 2_{1} 2_{1} 2_{1}$ & $P 2_{1} 2_{1} 2_{1}$ \\
\hline $\mathrm{a}[\AA]$ & $7.3849(5)$ & $7.429(2)$ \\
\hline $\mathrm{b}[\AA]$ & $5.8379(4)$ & $5.852(1)$ \\
\hline $\mathrm{c}[\AA]$ & $9.1937(6) 9$ & $.215(2)$ \\
\hline $\mathrm{V}\left[\AA^{3}\right]$ & 396.36 & 400.68 \\
\hline$Z^{2}$ & 4 & 4 \\
\hline$\mu\left[\mathrm{cm}^{-1}\right]$ & 148 & 142 \\
\hline Size $[\mu \mathrm{m}]$ & $96 \times 93 \times 93$ & $100 \times 140 \times 56$ \\
\hline \multicolumn{3}{|l|}{ Data Collection : } \\
\hline Diffractometer & R-AXIS RAPID & \\
\hline Monochrometor & Graphite & Graphite \\
\hline Radiation & $\operatorname{MoK} \alpha$ & $\operatorname{MoK} \alpha$ \\
\hline $2 \theta_{\max }\left[{ }^{\circ}\right]$ & 54.94 & 61.01 \\
\hline $\mathrm{h}_{\min }, \mathrm{h}_{\max }$ & $-9,5$ & $-10,8$ \\
\hline $\mathrm{k}_{\min }, \mathrm{k}_{\max }$ & $-7,7$ & $-8,8$ \\
\hline $1_{\min }, l_{\max }$ & $-11,11$ & $-13,13$ \\
\hline Observed reflection & 2766 & 3022 \\
\hline Unique reflection & 875 & 1194 \\
\hline $\mathrm{R}_{\text {int }}$. & 0.0440 & 0.0810 \\
\hline $\mathrm{R}_{\sigma}$ & 0.0329 & 0.0790 \\
\hline Temperature $[\mathrm{K}]$ & 298 & 298 \\
\hline \multicolumn{3}{|l|}{ Refinement: } \\
\hline Reflection used & 875 & 1194 \\
\hline Reflections with $\mathrm{Fo}>4 \sigma$ & 756 & 826 \\
\hline Parameters refined & 78 & 78 \\
\hline $\mathrm{R}_{1}($ all $)$ & 0.0361 & 0.056 \\
\hline $\mathrm{wR}_{2}$ (all) & 0.0778 & 0.1383 \\
\hline Goodness of fit & 1.081 & 1.026 \\
\hline
\end{tabular}

and the relationship between conichalcite and four selected arsenate minerals in the adelite group are discussed. The crystals of the minerals in the adelite group are characterized by low symmetry, because of which they have several degrees of freedom; this causes variations in site distortion in these crystals. A unique type of site distortion caused by the asymmetric electron orbit of the $\mathrm{Cu}$ ion is observed in conichalcite; this site distortion is responsible for the Jahn-Teller effect in this mineral. Hence, there is a possibility of the occurrence of spin-Peierls transition in pure conichalcite at low temperatures.

\section{SAMPLES AND ANALYTICAL METHODS}

The crystals states of several conichalcite specimens obtained from various sites in the National Science Museum (NSM), Japan, were examined by optical microscopy and diffraction methods. Among these samples, a small quantity of crystals obtained from Gosaisho mine, Fukushima, Japan (NSM number M11561), and Higgins mine, Arizona, USA (NSM number M25100), were found to be suitable for single-crystal structure analysis. The crystals obtained from Fukushima and Arizona were yellow-green
Table 2. Atomic coordinates and $U_{\text {eq }}$ values for conichalcite

\begin{tabular}{lccll}
\hline \multicolumn{1}{c}{ Atom } & $\mathrm{x}$ & $\mathrm{y}$ & $\mathrm{z}$ & $\mathrm{Ueq}$ \\
Arizona & & & & \\
$\mathrm{Ca}$ & $0.1168(2)$ & $0.2706(3)$ & $0.4258(2)$ & $0.0082(3)$ \\
$\mathrm{Cu}, \mathrm{Mg} *$ & $0.0050(2)$ & $-0.0004(3)$ & $0.7494(2)$ & $0.0093(3)$ \\
$\mathrm{As}$ & $0.3681(1)$ & $-0.2350(2)$ & $0.5802(1)$ & $0.0081(2)$ \\
$\mathrm{O}(1)$ & $0.1884(7)$ & $-0.255(1)$ & $0.6983(5)$ & $0.011(1)$ \\
$\mathrm{O}(2)$ & $0.541(1)$ & $-0.167(1)$ & $0.6912(7)$ & $0.016(2)$ \\
$\mathrm{O}(3)$ & $0.387(1)$ & $0.514(1)$ & $0.4908(7)$ & $0.015(2)$ \\
$\mathrm{O}(4)$ & $0.355(1)$ & $-0.007(1)$ & $0.4697(7)$ & $0.012(1)$ \\
$\mathrm{O}(5)$ & $0.139(1)$ & $0.254(1)$ & $0.6814(5)$ & $0.010(1)$ \\
$\mathrm{H}$ & $0.25(2)$ & $0.26(3)$ & $0.72(1)$ & $0.03(3)$ \\
\hline \multicolumn{1}{c}{ Fukushima } & & & & \\
$\mathrm{Ca}$ & $0.1169(3)$ & $0.2700(4)$ & $0.4253(2)$ & $0.0123(4)$ \\
$\mathrm{Cu}, \mathrm{Mg} * *$ & $0.0049(3)$ & $-0.0014(4)$ & $0.7490(2)$ & $0.0159(4)$ \\
$\mathrm{As}$ & $0.3679(1)$ & $-0.2355(2)$ & $0.5791(1)$ & $0.0167(3)$ \\
$\mathrm{O}(1)$ & $0.1895(9)$ & $-0.255(2)$ & $0.6957(7)$ & $0.017(1)$ \\
$\mathrm{O}(2)$ & $0.538(1)$ & $-0.171(1)$ & $0.690(1)$ & $0.025(2)$ \\
$\mathrm{O}(3)$ & $0.387(2)$ & $0.515(2)$ & $0.488(1)$ & $0.022(2)$ \\
$\mathrm{O}(4)$ & $0.355(2)$ & $-0.008(1)$ & $0.467(1)$ & $0.020(2)$ \\
$\mathrm{O}(5)$ & $0.137(1)$ & $0.255(2)$ & $0.681(1)$ & $0.020(1)$ \\
$\mathrm{H}$ & $0.23(2)$ & $0.21(3)$ & $0.70(2)$ & $0.02(4)$ \\
\hline
\end{tabular}

* Site occupancies: $\mathrm{Cu}(96 \%), \mathrm{Mg}(4 \%)$.

${ }^{* *}$ Site occupancies: $\mathrm{Cu}(87 \%), \mathrm{Mg}(13 \%)$.

and apple-green in color, respectively. Single crystals were chosen and used for X-ray diffraction (XRD) analysis and stereomicroscopic measurements. The crystals were mounted on a glass fiber and glued with epoxy resin. Single-crystal XRD was performed at the University of Tokyo on a Rigaku R-AXIS-RAPID diffractometer equipped with a Weissenberg-type imaging plate detector. The Weissenberg photographs confirmed the orthorhombic symmetry of the crystals and the $P 2_{1} 2_{1} 2_{1}$ space group. Intensity reflections were collected by an $\omega$-scan method using graphite-monochromatized $\mathrm{MoK} \alpha$ radiations. After Lorentz and polarization corrections, absorption correction was performed using the integration method on the basis of the observed arbitrary shape of the specimens. The structure was then solved by direct methods SIR97 (Altomare et al., 1999) and refined by alternating cycles of difference Fourier syntheses and full-matrix leastsquares refinements using SHELXL97 (Sheldrick, 1997). The crystal structure was solved using VESTA (Momma and Izumi, 2006). The chemical compositions of the specimens were analyzed quantitatively by electron-probe microanalysis, except for the $\mathrm{Cu}$ and As contents, because the observed $\mathrm{X}$-ray energies of the $\mathrm{Cu} K \alpha$ and $\mathrm{As} K \beta$ lines were very close. In this analysis, $\mathrm{Mn}, \mathrm{Fe}, \mathrm{Zn}$, and $\mathrm{Pb}$ were not detected. The $\mathrm{Mg} / \mathrm{Cu}$ ratio in each site was determined from the site occupancies of the refined structure on the basis of the Bragg intensity. The estimated chemical compositions of the crystals obtained from Fukushima and Arizona were $\mathrm{Ca}\left(\mathrm{Cu}_{0.87}, \mathrm{Mg}_{0.13}\right)\left(\mathrm{AsO}_{4}\right)(\mathrm{OH})$ and $\mathrm{Ca}\left(\mathrm{Cu}_{0.96}\right.$, $\left.\mathrm{Mg}_{0.04}\right)\left(\mathrm{AsO}_{4}\right)(\mathrm{OH})$, respectively. The intensity data and structure refinements of the crystals are summarized in 
Table 3. Displacement parameters for conichalcite

\begin{tabular}{lllllll}
\hline \multicolumn{1}{c}{ Atom } & $U_{11}$ & $U_{22}$ & $U_{33}$ & $U_{12}$ & $U_{13}$ & $U_{23}$ \\
Arizona & & & & & & \\
$\mathrm{Ca}$ & $0.0099(8)$ & $0.0082(7)$ & $0.0065(6)$ & $0.0008(7)$ & $0.0000(6)$ & $-0.00023(74)$ \\
$\mathrm{Cu}, \mathrm{Mg} *^{*}$ & $0.0102(5)$ & $0.0067(5)$ & $0.0109(4)$ & $-0.0002(3)$ & $0.0026(4)$ & $0.0011(3)$ \\
$\mathrm{As}$ & $0.0093(4)$ & $0.0071(3)$ & $0.0079(2)$ & $0.0003(4)$ & $0.0004(3)$ & $-0.0004(4)$ \\
$\mathrm{O}(1)$ & $0.010(3)$ & $0.011(3)$ & $0.012(2)$ & $0.003(4)$ & $0.006(2)$ & $-0.001(31)$ \\
$\mathrm{O}(2)$ & $0.014(4)$ & $0.017(3)$ & $0.016(3)$ & $-0.003(3)$ & $-0.007(3)$ & $-0.005(3)$ \\
$\mathrm{O}(3)$ & $0.023(4)$ & $0.011(3)$ & $0.013(3)$ & $-0.001(3)$ & $0.004(3)$ & $-0.002(3)$ \\
$\mathrm{O}(4)$ & $0.019(4)$ & $0.007(3)$ & $0.012(3)$ & $-0.002(3)$ & $0.008(3)$ & $0.002(2)$ \\
$\mathrm{O}(5)$ & $0.009(3)$ & $0.012(2)$ & $0.009(2)$ & $0.003(4)$ & $-0.002(2)$ & $-0.005(3)$ \\
\hline \multicolumn{1}{r}{ Fukushima } & & & & & & $-0.000(1)$ \\
$\mathrm{Ca}$ & $0.0141(9)$ & $0.0104(8)$ & $0.0124(7)$ & $0.0004(9)$ & $0.0004(7)$ & $0.0020(5)$ \\
$\mathrm{Cu}, \mathrm{Mg} * *$ & $0.0166(7)$ & $0.0118(6)$ & $0.0193(6)$ & $-0.0001(4)$ & $0.0020(5)$ & $-0.0004(7)$ \\
$\mathrm{As}$ & $0.0162(5)$ & $0.0146(5)$ & $0.0193(4)$ & $0.0004(5)$ & $0.0001(4)$ & $0.002(4)$ \\
$\mathrm{O}(1)$ & $0.021(4)$ & $0.013(3)$ & $0.018(3)$ & $0.002(4)$ & $0.005(3)$ & $0.003(4)$ \\
$\mathrm{O}(2)$ & $0.019(4)$ & $0.020(4)$ & $0.037(5)$ & $-0.007(3)$ & $-0.009(4)$ & $0.005(3)$ \\
$\mathrm{O}(3)$ & $0.037(6)$ & $0.007(3)$ & $0.023(4)$ & $-0.07(5)$ & $-0.002(4)$ & $0.001(3)$ \\
$\mathrm{O}(4)$ & $0.034(5)$ & $0.004(3)$ & $0.028(4)$ & $0.002(4)$ & $0.014(4)$ & $0.002(4)$ \\
$\mathrm{O}(5)$ & $0.019(4)$ & $0.017(3)$ & $0.023(3)$ & $-0.002(6)$ & $0.004(3)$ & \\
\hline
\end{tabular}

* Site occupancies: $\mathrm{Cu}(96 \%), \mathrm{Mg}(4 \%)$.

${ }^{* *}$ Site occupancies: $\mathrm{Cu}(87 \%), \operatorname{Mg}(13 \%)$.

Table 4. Selected interatomic distances $(\AA)$ and $\mathrm{O}-\mathrm{H}-\mathrm{O}$ bond angles (degree) for conichalcite

\begin{tabular}{|c|c|c|c|c|c|c|c|}
\hline $\begin{array}{l}\text { Arizona } \\
\text { As-O(1) }\end{array}$ & $1.714(4)$ & $\mathrm{Cu}-\mathrm{O}(1)$ & $2.087(5)$ & $\mathrm{Ca}-\mathrm{O}(1)$ & $2.537(4)$ & $\mathrm{H}-\mathrm{O}(5)$ & 0.74 \\
\hline As-O(2) & $1.679(5)$ & $\mathrm{Cu}-\mathrm{O}(1)^{*}$ & $2.064(5)$ & $\mathrm{Ca}-\mathrm{O}(2)$ & $2.515(5)$ & $\mathrm{H}-\mathrm{O}(2)$ & 1.97 \\
\hline $\mathrm{As}-\mathrm{O}(3)$ & $1.683(6)$ & $\mathrm{Cu}-\mathrm{O}(3)$ & $2.363(5)$ & $\mathrm{Ca}-\mathrm{O}(2)$ & $2.619(5)$ & $\mathrm{O}(5)-\mathrm{O}(2)$ & 2.690 \\
\hline As-O(4) & $1.679(5)$ & $\mathrm{Cu}-\mathrm{O}(4)$ & $2.288(5)$ & $\mathrm{Ca}-\mathrm{O}(3)$ & $2.483(6)$ & $\mathrm{O}(5)-\mathrm{H}-\mathrm{O}(2)$ & $163(2)$ \\
\hline$<$ As-O $>$ & 1.689 & $\mathrm{Cu}-\mathrm{O}(5)$ & $1.891(6)$ & $\mathrm{Ca}-\mathrm{O}(3)$ & $2.547(6)$ & & \\
\hline & & $\mathrm{Cu}-\mathrm{O}(5)^{*}$ & $1.887(6)$ & $\mathrm{Ca}-\mathrm{O}(4)$ & $2.449(6)$ & & \\
\hline & & $<\mathrm{Cu}-\mathrm{O}>$ & 2.097 & $\mathrm{Ca}-\mathrm{O}(4)$ & $2.585(6)$ & & \\
\hline & & & & $\mathrm{Ca}-\mathrm{O}(5)$ & $2.355(4)$ & & \\
\hline & & & & $<\mathrm{Ca}-\mathrm{O}>$ & 2.511 & & \\
\hline Fukushim & & & & & & & \\
\hline As-O(1) & $1.710(7)$ & $\mathrm{Cu}-\mathrm{O}(1)$ & $2.097(10)$ & $\mathrm{Ca}-\mathrm{O}(1)$ & $2.560(8)$ & $\mathrm{H}-\mathrm{O}(5)$ & 0.69 \\
\hline As-O(2) & $1.674(9)$ & $\mathrm{Cu}-\mathrm{O}(1) *$ & $2.085(10)$ & $\mathrm{Ca}-\mathrm{O}(2)$ & $2.515(11)$ & $\mathrm{H}-\mathrm{O}(2)$ & 2.08 \\
\hline As-O(3) & $1.694(10)$ & $\mathrm{Cu}-\mathrm{O}(3)$ & $2.357(11)$ & $\mathrm{Ca}-\mathrm{O}(2)$ & $2.645(10)$ & $\mathrm{O}(5)-\mathrm{O}(2)$ & 2.741 \\
\hline As-O(4) & $1.687(11)$ & $\mathrm{Cu}-\mathrm{O}(4)$ & $2.265(11)$ & $\mathrm{Ca}-\mathrm{O}(3)$ & $2.518(11)$ & $\mathrm{O}(5)-\mathrm{H}-\mathrm{O}(2)$ & $159(2)$ \\
\hline$<$ As-O $>$ & 1.691 & $\mathrm{Cu}-\mathrm{O}(5)$ & $1.894(12)$ & $\mathrm{Ca}-\mathrm{O}(3)$ & $2.523(12)$ & & \\
\hline & & $\mathrm{Cu}-\mathrm{O}(5)^{*}$ & $1.887(11)$ & $\mathrm{Ca}-\mathrm{O}(4)$ & $2.441(11)$ & & \\
\hline & & $<\mathrm{Cu}-\mathrm{O}>$ & 2.098 & $\mathrm{Ca}-\mathrm{O}(4)$ & $2.576(12)$ & & \\
\hline & & & & $\mathrm{Ca}-\mathrm{O}(5)$ & $2.348(10)$ & & \\
\hline & & & & $<\mathrm{Ca}-\mathrm{O}>$ & 2.516 & & \\
\hline
\end{tabular}

Table 1. The final atomic coordinates and $U_{e q}$ values are listed in Table 2, the anisotropic displacement parameters in Table 3, and the interatomic distances in Table 4.

\section{RESULTS AND DISCUSSION}

\section{Description of crystal structure}

The conichalcite crystal consists of three types of distorted polyhedra: an $\mathrm{AsO}_{4}$ tetrahedron, a $\mathrm{CuO}_{4}(\mathrm{OH})_{2}$ octahedron, and a $\mathrm{CaO}_{7}(\mathrm{OH})_{2}$ square antiprism. Basically, the crystal comprises edge-sharing chains of the $\mathrm{CuO}_{4}(\mathrm{OH})_{2}$ octahedron that run parallel to the $\boldsymbol{b}$-axis (Fig. 1). The $\mathrm{CuO}_{4}(\mathrm{OH})_{2}$ chains are linked by the vertices of the $\mathrm{AsO}_{4}$ tetrahedron to form a three-dimensional framework. The $\mathrm{AsO}_{4}$ tetrahedron is isolated from the others. Ca resides a square antiprismatic cavity in the framework so as to form a distorted $\mathrm{CaO}_{7}(\mathrm{OH})$ square antiprism with eight oxygen atoms (Fig. 2).

\section{Hydrogen bonding}

The position of the hydrogen atom in the conichalcite crystal is determined by the difference Fourier method. 


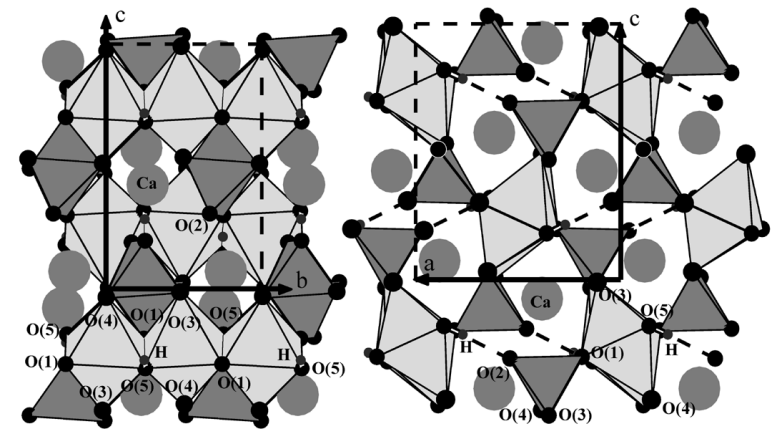

Figure 1. Crystal structure of conichalcite, $\mathrm{CaCu}\left(\mathrm{AsO}_{4}\right)(\mathrm{OH})$, as viewed along the chains in the edge-sharing $\mathrm{Cu}$ octahedron and As tetrahedra on either side (left) and along the (010) direction (right).

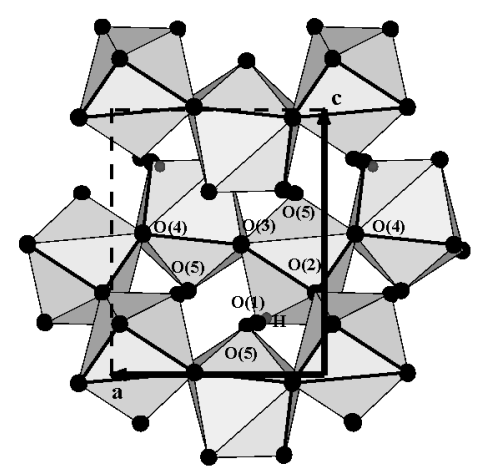

Figure 2. Crystal structure of conichalcite, showing the three-dimensional network of $\mathrm{Ca}$ square antiprisms projected down the $\boldsymbol{c}$-axis. Ca polyhedra chains with common $\mathrm{O}(3)-\mathrm{O}(4)$ edges develop along the $\boldsymbol{a}$-axis.

The chemical environment of the hydrogen atoms in the conichalcite is shown in Figure 3. The bond-valence sums are calculated using the method prescribed by Brown and Altermatt (1985) without considering the contribution by the hydrogen atom. The valences of $\mathrm{O}(2)$ and $\mathrm{O}(5)$ are lower than 2.0, whereas those of the other $\mathrm{O}$ atoms are close to 2.0 (Table 5). In addition, $\mathrm{O}(5)$ does not coordinate with $\mathrm{As}^{5+}$; the $\mathrm{Ca}-\mathrm{O}(5)(2.35 \AA)$ and $\mathrm{Cu}-\mathrm{O}(5)(1.89$ $\AA$ ) bond distances are the shortest metal-oxygen distances in the $\mathrm{Ca}$ and $\mathrm{Cu}$ polyhedra, respectively. $\mathrm{O}(5)$ combines with $\mathrm{H}^{+}$instead of $\mathrm{As}^{5+}$ and approaches the $\mathrm{Ca}$ and $\mathrm{Cu}$ atoms, thereby increasing the charge contribution. Qurashi and Barns (1963) reported that $\mathrm{O}(5)$ and $\mathrm{O}(2)$ atoms may be associated with a hydrogen-bonding system. On the basis of bond-valence and stereochemical considerations, we propose that the $\mathrm{O}(5)$ atom belongs to the $\mathrm{OH}^{-}$group and that the $\mathrm{O}(2)$ atom is the hydrogen bond acceptor. On the basis of the correlation between the donor-acceptor distance and the $\mathrm{H}-\mathrm{O}(2)$ bond valence (Brown and Altermatt, 1985), the observed $\mathrm{O}(5)-\mathrm{O}(2)$ distances indicate that the $\mathrm{H}-\mathrm{O}(2)$ bond has a valence of $0.20-0.24$, which is

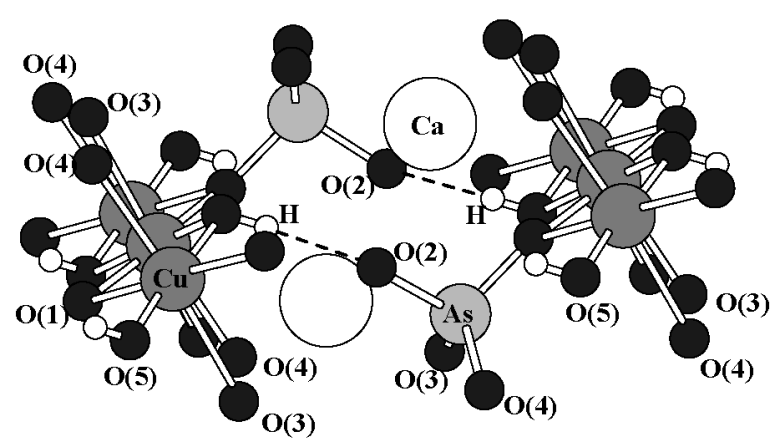

Figure 3. Chemical environment of the hydrogen atoms in the conichalcite structure.

Table 5. Summary of the results of bond-valence analysis for conichalcite

\begin{tabular}{lllll}
\hline Arizona & $\mathrm{Ca}$ & $\mathrm{As}$ & $\mathrm{Cu}$ & $\mathrm{SUM}$ \\
$\mathrm{O}(1)$ & 0.213 & 1.142 & 0.337 & 2.046 \\
& & & 0.354 & \\
$\mathrm{O}(2)$ & 0.222 & 1.258 & & 1.654 \\
& 0.174 & & & \\
$\mathrm{O}(3)$ & 0.239 & 1.241 & 0.153 & 1.858 \\
& 0.225 & & & \\
$\mathrm{O}(4)$ & 0.292 & 1.265 & 0.199 & 1.956 \\
$\mathrm{O}(5)$ & 0.200 & & & \\
& 0.348 & & 0.565 & 1.472 \\
SUM & 1.913 & 4.906 & 2.167 & \\
\hline Fukushima & $\mathrm{Ca}$ & $\mathrm{As}$ & $\mathrm{Cu}$ & $\mathrm{SUM}$ \\
$\mathrm{O}(1)$ & 0.201 & 1.167 & 0.318 & 2.023 \\
& & & 0.337 & \\
O(2) & 0.224 & 1.300 & & 1.685 \\
& 0.161 & & & \\
O(3) & 0.226 & 1.238 & 0.160 & 1.839 \\
O(4) & 0.215 & & & \\
O(5) & 0.284 & 1.248 & 0.203 & 1.920 \\
SUM & 0.185 & & & \\
\hline & 0.342 & & 0.547 & 1.461 \\
& & & 0.572 & \\
\hline & 1.838 & 4.953 & 2.137 & \\
\hline
\end{tabular}

in the range expected for an acceptor. These values are consistent with the $\mathrm{H}-\mathrm{O}(2)$ valences determined by the bond-valence-sum method. Thus, a normal hydrogen bond is suggested to have been formed in the structure.

\section{Distortions of $\mathrm{CuO}_{4}(\mathrm{OH})_{2}$ and $\mathrm{AsO}_{4}$ polyhedra and possibility of spin-Peierls transition}

The $\mathrm{CuO}_{4}(\mathrm{OH})_{2}$ octahedron in the conichalcite crystal is distorted; further, the octahedra in the samples obtained from Fukushima and Arizona comprise a short equatorial $\mathrm{Cu}-\mathrm{O}$ bond and a long apical $\mathrm{Cu}-\mathrm{O}$ bond, respectively (Fig. 4a). This characteristic difference in the $\mathrm{Cu}-\mathrm{O}$ bonds between the $\mathrm{CuO}_{4}(\mathrm{OH})_{2}$ octahedra in conichalcite samples 
(a)

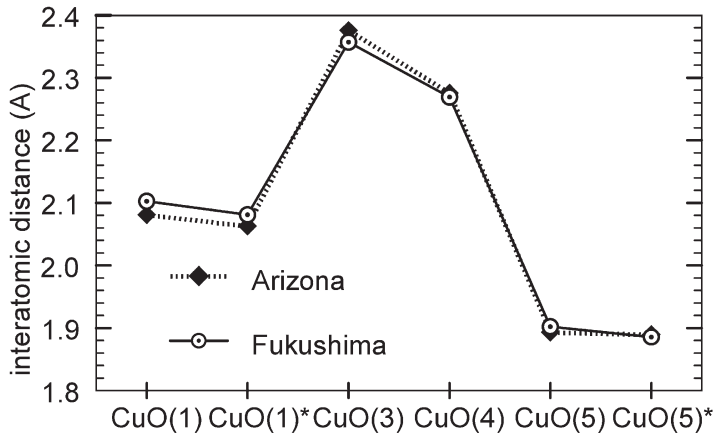

(b)

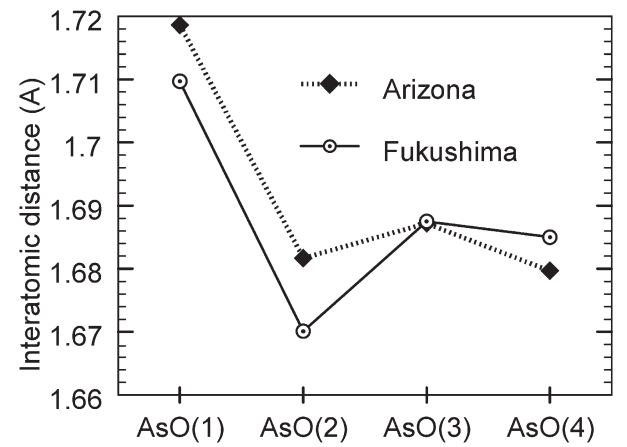

Figure 4. Interatomic distances (a) $\mathrm{Cu}-\mathrm{O}$ and (b) $\mathrm{As}-\mathrm{O}$ in the conichalcite samples.

obtained from these two regions should be attributed to the existence of hydrogen bonding and the Jahn-Teller effect caused by the distortion of the electron orbit of the $\mathrm{Cu}$ ion. Hydrogen bonding causes further shortening of the $\mathrm{Cu}-\mathrm{O}(5)$ and $\mathrm{Cu}-\mathrm{O}(5)^{*}$ bonds. $\mathrm{O}(5)$ combines with $\mathrm{H}^{+}$ instead of $\mathrm{As}^{5+}$ and approaches $\mathrm{Cu}$, thereby increasing the charge contribution. The Jahn-Teller effect causes axial stretching of the $\mathrm{Cu}-\mathrm{O}(3)$ and $\mathrm{Cu}-\mathrm{O}(4)$ bonds and equatorial shortening of the $\mathrm{Cu}-\mathrm{O}(1), \mathrm{Cu}-\mathrm{O}(1)^{*}, \mathrm{Cu}-\mathrm{O}(5)$, and $\mathrm{Cu}-\mathrm{O}(5)^{*}$ bonds. A similar Jahn-Teller distortion has been reported in related $\mathrm{Cu}$ minerals such as duftite $(\mathrm{PbCu}$ $\left(\mathrm{AsO}_{4}\right)(\mathrm{OH})$, Kharisun et al., 1998). The directions of expansion and contraction caused by the Jahn-Teller effect in duftite differ from those caused by the Jahn-Teller effect in conichalcite, whereas the effect of bond shortening caused by hydrogen bonding is the same in both these minerals. The anisotropy in the thermal vibration in conichalcite (Table 3 ) is also markedly different from that in duftite. It is important to show that the large difference in the distortion of the polyhedral sites between conichalcite and duftite results from the difference between $\mathrm{Ca}$ and $\mathrm{Pb}$. A detailed discussion on the same is presented subsequently.

Crystals may show interesting characteristics when the atomic arrangement in them is satisfactory. However, there is a possibility of certain unique characteristics of these crystals remaining undetected in natural materials. One may observe spin-Peierls transition in pure conichal-
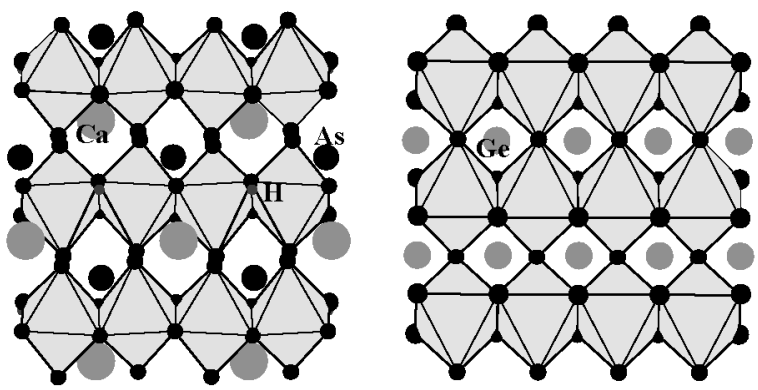

Figure 5. $\mathrm{CuO}_{6}$ chains in conichalcite (right) and $\mathrm{CuGeO}_{3}$ (left).

cite at low temperatures. The occurrence of this type of transition cannot be expected in duftite, even though the $\mathrm{Cu}$ system in duftite is identical to that in conichalcite. Spin-Peierls transition occurs when a system of uniform Heisenberg AF linear chains transforms into that of dimerized or alternating $\mathrm{AF}$ linear chains. $\mathrm{CuGeO}_{3}$ is the first example of an inorganic spin-Peierls system (Hase et al., 1993). The $\mathrm{CuGeO}_{3}$ crystal has a unique arrangement in which corner-sharing $\mathrm{GeO}_{4}$ tetrahedral chains are linked by edge-sharing $\mathrm{CuO}_{6}$ octahedral chains (Yoshiasa et al., 2000). In this structure, the $\mathrm{CuO}_{6}$ octahedral chains play the role of Heisenberg AF linear chains. Similar $\mathrm{CuO}_{6}$ chains and octahedral distortions are also found in the conichalcite crystal. Additionally, at $0.1 \mathrm{MPa}$, the observed $\mathrm{Cu}-\mathrm{Cu}$ distances in conichalcite (Arizona sample: $2.92 \AA$; Fukushima sample: $2.93 \AA$ ) are close to those in $\mathrm{CuGeO}_{3}(2.94 \AA$ ) (Fig. 5).

The observed As-O distances $(1.69 \AA)$ are shorter than the expected value $(1.72 \AA)$ calculated on the basis of the ionic bonding distances decided by statistically (Shannon, 1976) (Fig. 4b). This indicates that the contribution of covalent bonding in As-O is considerably high. Though most covalently bonded tetrahedral sites are relatively undistorted, the change in the distances is large (1.72-1.67 $\AA$ ), and the tetrahedral site in the conichalcite structure examined in this study is highly distorted. This large distortion is expected to have resulted from the distortion of the electron orbit of the $\mathrm{Cu}$ ion, which in turn causes the Jahn-Teller effect.

\section{Comparison of conichalcite and related minerals}

In general, the physical and chemical properties of a substance depend on the crystal structure, i.e., differences in their ionic radii and electronic structures. Therefore, it is important to carry out a comparative study of different isomorphous minerals in order to determine the exact structure of conichalcite. In this study, interatomic distances $\mathrm{M}-\mathrm{O}(\mathrm{M}$ : $\mathrm{Ni}, \mathrm{Cu}, \mathrm{Zn})$ and $\mathrm{As}-\mathrm{O}$ of five isomorphous minerals such as conichalcite, austinite $[\mathrm{CaZn}$ $\left(\mathrm{AsO}_{4}\right)(\mathrm{OH})$; Clark et al., 1997], nickel austinite [CaNi 
(a)

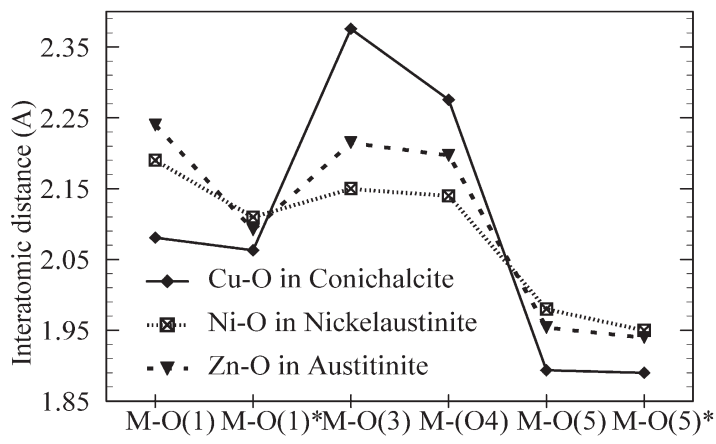

(b)

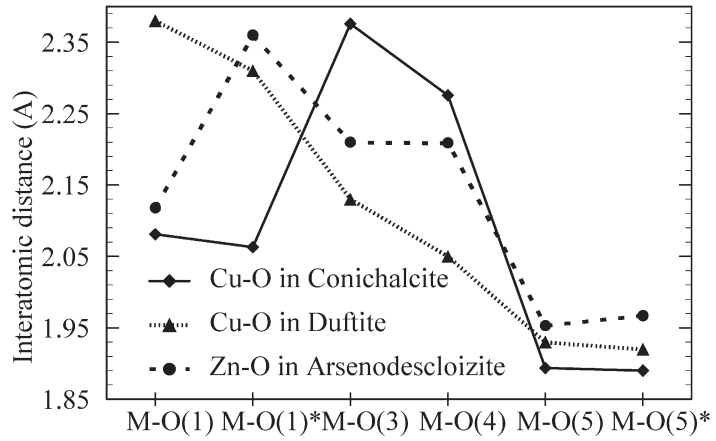

Figure 6. Comparison of interatomic distances $\mathrm{M}-\mathrm{O}(\mathrm{M}: \mathrm{Ni}, \mathrm{Cu}$, $\mathrm{Zn}$ ) in conichalcite with those in isomorphous minerals in the (a) $\mathrm{Ca}$ series and (b) $\mathrm{Pb}$ series.

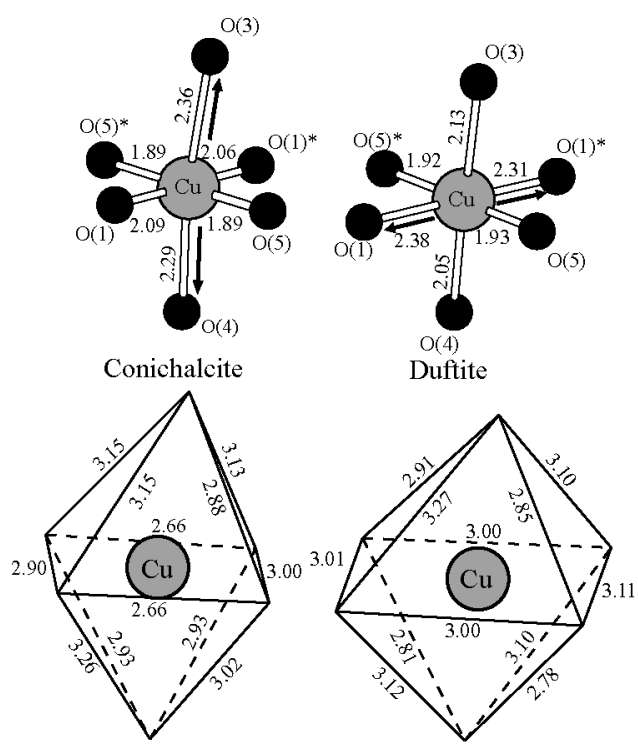

Figure 7. $\mathrm{B}^{2+}-\mathrm{O}$ and $\mathrm{O}-\mathrm{O}$ distances at the $\mathrm{B}^{2+}$ octahedral site in conichalcite and duftite.

$\left(\mathrm{AsO}_{4}\right)(\mathrm{OH})$; Cesbron et al., 1987], duftite $\left(\mathrm{PbCu}\left(\mathrm{AsO}_{4}\right)\right.$; Kharisun et al., 1998), and arsendescloizite $\left[\mathrm{PbZn}\left(\mathrm{AsO}_{4}\right)\right.$ $(\mathrm{OH})$; Keller et al., 2003] are compared.

The $\mathrm{M}-\mathrm{O}$ distances in the minerals of the $\mathrm{Ca}$ series show a very similar trend, although the $\mathrm{Ni}-\mathrm{O}(1)$ and $\mathrm{Zn}-\mathrm{O}(1)$ distances (in nickel austinite and austinite, respectively) are longer than the $\mathrm{Cu}-\mathrm{O}(1)$ distance in (a)

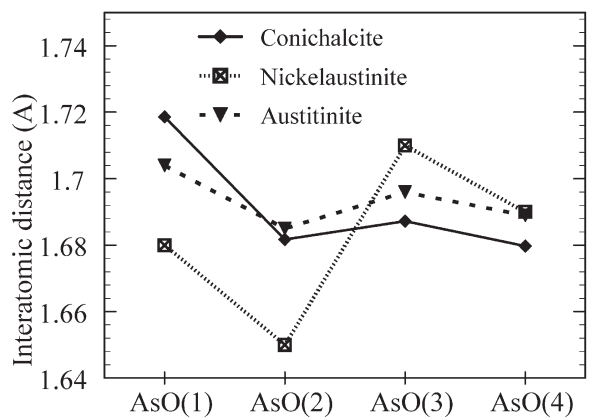

(b)

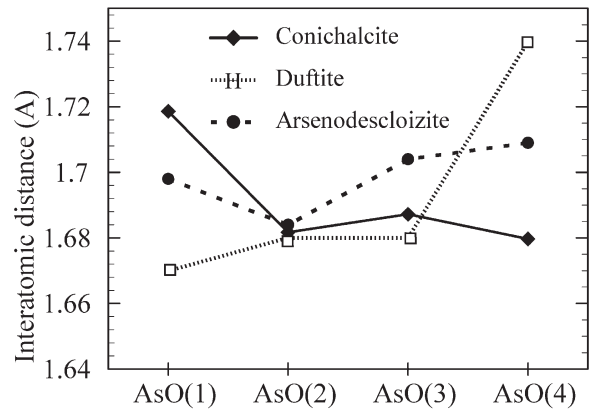

Figure 8. Comparison of interatomic distances $\mathrm{As}^{-} \mathrm{O}$ in conichalcite with those in isomorphous minerals of (a) Ca series and (b) $\mathrm{Pb}$ series.

conichalcite (Fig. 6a). The $\mathrm{M}-\mathrm{O}(5)$ and $\mathrm{M}-\mathrm{O}(5)^{*}$ distances are the shortest among all the $\mathrm{M}-\mathrm{O}$ distances because $\mathrm{O}(5)$ combines with $\mathrm{H}^{+}$instead of $\mathrm{As}^{5+}$ and approaches $\mathrm{Cu}$, thereby increasing charge contribution. Isomorphous minerals containing $\mathrm{Ca}$ show effects similar to those shown by conichalcite. The $\mathrm{M}-\mathrm{O}(3)$ and $\mathrm{M}-\mathrm{O}(4)$ distances in conichalcite are the longest among all the $\mathrm{M}-\mathrm{O}$ distances, indicating the Jahn-Teller effect caused by the $\mathrm{Cu}$ atoms.

On the other hand, the $\mathrm{M}-\mathrm{O}$ distances in minerals from the $\mathrm{Pb}$ series, such as duftite $(\mathrm{M}=\mathrm{Cu})$ and arsendescloizite $(\mathrm{M}=\mathrm{Zn})$, are markedly different from those in conichalcite, which is a mineral in the Ca series (Fig. 6b). A system with low symmetry has several degrees of freedom in its crystal structure. The type of site distortion caused by the asymmetric electron orbit of the transition metal ion is distinctly different in different chemical systems. For example, the apical $\mathrm{Cu}-\mathrm{O}(3)$ and $\mathrm{Cu}-\mathrm{O}(4)$ bonds in duftite are shorter than those in conichalcite, while the equatorial $\mathrm{Cu}-\mathrm{O}(1)$ and $\mathrm{Cu}-\mathrm{O}(1)^{*}$ bonds are the longest among the six neighbors. These features related to $\mathrm{Cu}$ readily suggest that the Jahn-Teller distortion in duftite is different from that in conichalcite (Fig. 7). A similar discussion can be made for arsendescloizite, where the trend observed in the $\mathrm{Zn}-\mathrm{O}$ distances is different from that observed for the corresponding austinite. Therefore, the electronic and configurational effects at the octahedral $\mathrm{M}$ site differ between the crystals of the miner- 
als in the $\mathrm{Pb}$ series and those of the minerals in the $\mathrm{Ca}$ series.

Figure 8 shows the geometrical features of the As tetrahedron in the minerals of the $\mathrm{Ca}$ and $\mathrm{Pb}$ series. In general, tetrahedral sites are relatively undistorted because the chemical bonding is considerably covalent; this idea is reflected in the rather undistorted As tetrahedron found in conichalcite, austinite, and arsenodescloizite. Nevertheless, a significant distortion is clearly found in the corresponding As tetrahedra in nickel austinite and duftite. In particular, the As- $\mathrm{O}(2)$ distance in nickel austinite $(1.65$ $\AA$ ) and the As- $\mathrm{O}(4)$ distance in duftite $(1.74 \AA)$ are the shortest and the longest among all the As-O distances in the minerals of the $\mathrm{Ca}$ and $\mathrm{Pb}$ series, respectively. There is a large difference from mean distance to $\sim 0.05 \AA$, and the degree of distortion is exceptionally high at the tetrahedral site. These differences in the As- $\mathrm{O}$ distances may be attributed to the differences in the ionic radii and electronic structures, which result from the differences in the chemical compositions of these minerals.

\section{REFERENCES}

Altomare, A., Burla, M.C., Camalli, M., Cascarano, G.L., Giacovazzo, C., Guagliardi, A., Moliterni, A.G.G., Polidori, G. and Spagna, R. (1999) SIR97: a new tool for crystal structure determination and refinement. Journal of Applied Crystallography, 32, 115-119.

Berry, L.G. (1951) Observations on conichalcite, cornwallite euchroite liroconite and olivenite. American Mineralogist, 36, 484-503.

Brown, I.D. and Altermatt, D. (1985) Bond-valence parameters obtained from a systematic analysis of the Inorganic Crystal Structure Database. Acta Crystallographica, B41, 244-247.

Cesbron, F.P., Ginderow, D., Giraud, R., Pelisson, P. and Pillard, F. (1987) La nickelaustinite $\mathrm{Ca}(\mathrm{Ni}, \mathrm{Zn})\left(\mathrm{AsO}_{4}\right)(\mathrm{OH})$ : nouvelle espèrale minérale du district cobalto-nickelifère de $\mathrm{Bou}^{-}$ Azzer, Maroc. Canadian Mineralogist, 25, 401-407.

Clark, L.A., Pluth, J.J., Steele, I., Joseph, V. and Sutton, S.R. (1997) Crystal structure of austinite, $\mathrm{CaZn}\left(\mathrm{AsO}_{4}\right) \mathrm{OH}$. Miner- alogical Magazune, 61, 677-683.

Hase, M., Terasaki, I. and Uchinokura, K. (1993) Observation of the spin-Peierls transition in linear $\mathrm{Cu}^{2+}$ (spin-1/2) chains in an inorganic compound $\mathrm{CuGeO}_{3}$. Physical Review Letters, 70, 3651-3654.

Jambor, J.L., Owens, D.R. and Dutrizac, J.E. (1980) Solid solution in the adelite group of arsenates. Canadian Mineralogist, 18, 191-195.

Keller, P., Lissner, F. and Schleid, T. (2003) The crystal structure of arsenodescloizite, $\mathrm{PbZn}(\mathrm{OH})\left[\mathrm{AsO}_{4}\right]$, from Tsumeb (Namibia). Neues Jahrbuch für Mineralogie, Monatshefte, 8, 374-384.

Kharisun, Taylor, M.R., Bevan, D.J.M. and Pring, A. (1998) The crystal chemistry of duftite, $\mathrm{PbCuAsO}_{4}(\mathrm{OH})$ and the $\beta$-duftite problem. Mineralogical Magazine, 62, 1, 121-130.

Momma, K and Izumi, F (2006) An integrated three-dimensional visualization system VESTA using wxWidgets. Commission on Crystallographic Computing, IUCr Newsletter, 7, 106119.

Qurashi, M.M. and Barnes, W.H. (1963) The structures of the minerals of the descloizite and adelite groups: IV - descloizite and conichalcite (part 2) The structure of conichalcite. Canadian Mineralogist, 7, 561-577.

Radcliffe, D. and Simmons, W.B.Jr. (1971) Austinite: chemical and physical properties in relation to conichalcite. American Mineralogist, 56, 1359-1365.

Shannon, R.D. (1976) Revised Effective Ionic Radii and Systematic Studies of Interatomic Distances in Halides and Chalcogenides. Acta Crystallographica, A32, 751-767.

Sheldrick, G.M. (1997) SHELXL-97 - A program for crystal structure refinement. University of Göttingen, Germany, 972 .

Taggart, J.E. and Foord, E.E. (1980) Conichalcite, cuprian austinite, and plumboan conichalcite from La Plata Country, Colorado, USA. Mineralogical Record, 11, 37-38.

Yoshiasa, A., Yagyu, G., Ito, T., Yamanaka, T. and Nagai, T. (2000) Crystal Structure of the High Pressure Phase(II) in $\mathrm{CuGeO}_{3}$. Zeitschrift füranorganische und allgemeine Chemie, 626, 36-41.

Manuscript received April 30, 2008

Manuscript accepted November 17, 2008

Published online April 24, 2009

Manuscript handled by Yasuhiro Kudoh 